w Poznaniu

kamel@amu.edu.pl

\title{
Listy do króla w sprawach wiary w polskich protestanckich Bibliach XVI i XVII wieku
}

Aвstract: Meller Katarzyna, Listy do króla $w$ sprawach wiary $w$ polskich protestanckich Bibliach XVI i XVII wieku (Dedicatory Epistles to the King in Matters of Faith in the Polish Protestant Bibles in the $16^{\text {th }}$ and $17^{\text {th }}$ Century). "Poznańskie Studia Slawistyczne" 10 . Poznań 2016. Publishing House of the Poznań Society for the Advancement of the Arts and Sciences, pp. 179-195. ISSN 2084-3011.

The article examines religious topics in dedicatory letters for the Polish Protestant Bibles of the $16^{\text {th }}$ and $17^{\text {th }}$ century. The New Testament published by Jan Seklucjan (1551-1553), the Brest Bible (1563) and the Gdansk Bible (1632) were dedicated to the reigning kings towards whom the Protestants expressed their expectations about the place of the Church / religion in the state and the role of the ruler. The dedicatory letters by Seklucjan, Mikolaj Radziwill and Krzysztof Radziwill highlighted the concept of the primacy of secular authority over the Church, namely, the sovereignty of the monarch, personifying the majesty and law of the Republic over the Church of God, i.e. people who constitute the community of faith. According to the Polish political status, king, due to his office, played the role of the "servant of the Republic", and as the guardian of the legal order, was not to be the ruler of conscience, but the guardian of freedom of speech and religion.

Keywords: reformation in Poland; state - Church relation; Jan Seklucjan; the Brest Bible; the Gdansk Bible; dedicatory letter; King Sigismund II Augustus; King Władysław IV Vasa

Idee reformacji, w tym wizja Kościoła ubogiego, realizującego proste prawdy Ewangelii, niezależnego od Rzymu, podległego władzy świeckiej, spotkały się w Rzeczpospolitej z kultywowaną od XV wieku koncepcją państwa świeckiego i demokratycznego, najsilniej wyrażoną w szlacheckim ruchu egzekucyjnym. Antyklerykalizm elit szlacheckich, bez względu na konfesję (Augustyniak 2013: 7-128), miał silne oparcie w republikańskich ideałach politycznych, a wolność wyznania uznana została „za niezbywalny atrybut swobód obywatelskich zagwarantowanych prawem powszechnym Rzeczypospolitej” (Sucheni-Grabowska 1996: 307). Prymat Kościoła nad państwem był dla elit szlacheckich XVI wieku nie do 
przyjęcia. Osią konfliktu kleru i świeckich była negowana przez szlachtę prawno-społeczna odrębność stanu duchownego, a spór koncentrował się na kwestiach ekonomiczno-prawnych: zrównania szlachty i duchowieństwa w obowiązku wyprawy wojennej i świadczeniach podatkowych, ograniczeniu sądownictwa duchownego; nadto stawiano kwestię uniezależnienia od Rzymu, odstąpienia od annat i papieskiego prawa prowizji beneficjów. Wraz z rozwojem protestantyzmu i zróżnicowaniem konfesyjnym społeczeństwa $\mathrm{w}$ antyklerykalnym dyskursie politycznym pojawił się nowy wątek: pokoju wyznaniowego, gwarancji swobody wyznania i równouprawnienia w życiu politycznym bez względu na wyznanie. W początkowym okresie reformacji protestanccy krytycy kościelnego status quo wzmocnili antyklerykalny tenor argumentami natury moralno-obyczajowej, przedstawiając kler jako inutilis pondus terrae (Czapska 1928: 12). Wśród argumentów religijnych największą moc miało na nowo zdefiniowane pojęcie Kościoła: Kościół-ecclesia to wspólnota wiernych, congregatio sanctorum, communio praedistinatorum (Winiarska 2004: 272). Konsekwencją duchowego rozumienia Kościoła była idea powszechnego kapłaństwa (wykluczająca odrębność stanu duchownego) i wzajemnego nauczania (negująca nauczycielski urząd Kościoła rzymskiego). Protestancka duchowość, ale także kultura teologiczna i polemiczna, w centrum postawiła Biblię, najważniejszą księgę chrześcijaństwa.

Na takim ideowym gruncie wyrosła koncepcja nadrzędności władzy świeckiej nad kościelną, a dokładniej: zwierzchnictwa monarchy, uosabiającego majestat i prawo Rzeczpospolitej, nad Kościołem Bożym (w domyśle: ewangelickim). W polskich realiach politycznych król, z racji swego urzędu i roli „sługi Rzeczpospolitej”, strażnika porządku prawnego, którą wyznaczał mu mieszany ustrój państwa, nie byłby więc wła d cą sumień, ale strażnikiem wolności słowa i wyznania. Dążenie do podniesienia politycznego autorytetu króla uwidacznia się w wywodach pisarzy politycznych, którzy starali się zdefiniować zakres władzy monarszej, znaczenie prawa pisanego i prawnego zwyczaju, a także mechanizmy życia społecznego w relacji do prawa i powinności królewskich (Sucheni-Grabowska 1994: 53-115). Wszystkie te wypowiedzi utrwalały przekonanie, że król działa w granicach prawa, że „służba królowi i prawu to droga do wolności, król bowiem uosabia prawo. Stąd posłuszeństwo wobec niego jest równoznaczne z działaniem na rzecz swobód obywatelskich" 
(Sucheni-Grabowska 1994: 65). Jednocześnie w wolnym (prawnym) państwie cnotliwi (prawi) obywatele, kierując się dobrem Rzeczpospolitej, mogą napominać króla (Pietrzyk-Reeves 2010: 57) także w sprawach kościelno-religijnych. Sądząc po liczbie wypowiedzi - adresowanych do króla wprost lub pośrednio - głoszących, że to monarcha jest (winien być) opiekunem Kościoła (w ewangelickim rozumieniu), można wnioskować, że był to pogląd wśród protestantów powszechny (Meller 2004: 37-81). Przypominanie, skąd pochodzi moc królewskiego urzędu i o tym, że król jest znakiem obecności Boga w ziemskim królestwie etc., podbudowywało - według protestanckich polemistów - prestiż tronu w spornych kwestiach kościelno-wyznaniowych i nakładało na monarchę obowiązek dbałości o właściwe sprawowanie kultu. Rzymski Kościół nie jest potrzebny do zbawienia, a sojusz tronu i ołtarza nie służy państwu ${ }^{1}$. Potrzebna jest natomiast wiara i głoszenie „szczerego słowa Bożego”, które zbudują moralne społeczeństwo, prawdziwie chrześcijańską Rzeczpospolitą, współtworzoną przez dobre, sprawiedliwe rządy i prawych, mądrych obywateli. Polska renesansowa filozofia i praktyka polityczna odwoływały się do koncepcji państwa formułowanej przez Arystotelesa i Cycerona: grecki termin politea i rzymski res publica jednako ewokowały ideę państwa jako „rzeczy publicznej”, praworządnej wspólnoty politycznej zapewniającej wszystkim jej członkom pożytek i umożliwiającej dobre życie, zrównującej najwyższe cele człowieka i państwa (Pietrzyk-Revees 2010: 40-41). W dyskursie protestantów (luteranów, kalwinistów, braci czeskich) cel państwa jawi się więc jako etyczny, co nie unieważnia ostatecznej perspektywy transcendentnej wobec świeckiej doczesności. Tu otwierało się miejsce dla debaty o równouprawnieniu wyznań (później o tolerancji religijnej), swobodzie sumienia i konfesji. Inaczej rzecz ujmowała doktryna katolicka, głosząca, że nie ma zbawienia poza Kościołem, a ortodoksyjni katoliccy politycy twierdzili, iż „rozróżnienie w wierze” narusza fundamenty państwa. Problematyka stosunków wyznaniowych w Rzeczpospolitej, analizowana czy to na podstawie dokumentów życia politycznego, czy traktatów polityczno-prawnych, czy zaangażowanej w te kwestie publicystyki, literatury

${ }^{1}$ W XVI wieku taki pogląd głosił np. Stanisław Orzechowski, przekonany, że kapłan i król wspólnie prowadzą Rzeczpospolitą do jej celu, czyli królestwa niebieskiego; celem państwa ma być szczęście wieczne, ponaddoczesne (Pietrzyk-Reeves 2010: 54). 
polemicznej, perswazyjnej lub stricte religijnej, ma długą tradycję badań (cf. Kriegseisen 2010: 411-673), lecz ciągle warto oświetlać różne aspekty tej intrygującej i stale aktualnej materii.

Do przedstawianej tu kwestii badacz słowa pisanego dorzucić może obserwacje poczynione w tekstach dla tej materii nieoczywistych i nierozpatrywanych pod kątem problematyki stosunków wyznaniowych. W tym miejscu pragnę zatrzymać się przy edycjach Biblii, a dokładnie: listach dedykacyjnych umieszczanych w szesnastowiecznych wydaniach polskich protestanckich tłumaczeń Pisma Świętego, adresowanych do aktualnie panującego króla ${ }^{2}$. Spośród wielu polskich protestanckich edycji biblijnych z wieków XVI i XVII przywołuję tu luterański Nowy Testament w tłumaczeniu Stanisława Murzynowskiego wydany przez Jana Seklucjana w Królewcu (Testamentu Nowego część pierwsza 1551, Testamentu Nowego czesść wtora a ostateczna 1552 i Nowy Testament zupetny 1553), kalwińską Biblię brzeską (1563) i Biblię gdańską (1632). Porównawczo odnoszę się także do Biblii katolickich: Leopolity (1561) oraz Jakuba Wujka (1599).

Skierowanie uwagi właśnie na dedykacje Pisma Świętego wynika z przesłanek kulturowo-religijnych. Wokół Biblii zogniskowane są najważniejsze problemy, które ówcześnie szeroko dyskutowano. I rzecz nie w kwestiach teologicznych, które wywiedziono z uważnej lektury Pisma, wolnej od scholastycznych komentarzy i nieskrępowanej kościelną Tradycją. Reformacyjne idee naprawy Kościoła spotkały się z renesansową rzeczywistością kulturową. Splot wielu czynników sprawił, że XVI wiek stał się prawdziwie złotym wiekiem Biblii. Fundamentalna zasada teologiczna protestantyzmu: sola Scriptura, sola fide i sola gratia, a nadto społeczna potrzeba modernizacji oraz odzyskane, dzięki humanistycznym i renesansowym impulsom, podmiotowość i indywidualizm sprawiły, że wolny i powszechny dostęp do polskiej Biblii był świeckim postulatem, oczekiwaniem ludzi, którzy czują się Kościołem. Polak w Polsce, czytając i studiując Biblię w języku polskim, buduje swoją wiarę i modli się (najlepiej słowem biblijnym) w rodzimym języku. Zbędni w tym są pośrednicy: kapłani i nauczycielski urząd Kościoła.

Dedykowanie nowo wydanej Biblii królowi nie było aktem nadzwyczajnym. Listy dedykacyjne w Bibliach ze względu na swoją specyfikę

${ }^{2} \mathrm{Z}$ dedykacji wybieram tylko te wątki, które odnoszą się do kwestii wyznaniowych. 
- adresata, autorów, kulturowo-wyznaniowy i polityczny kontekst publikacji - pozwalają na wgląd w kwestie stosunków wyznaniowych w Rzeczpospolitej z nieco innej strony niż ta, która rysuje się $\mathrm{w}$ tekstach polemicznych czy swoiście ,programowych”, formułujących teorie idealnych relacji między świeckim zwierzchnictwem a wspólnotami wyznaniowymi, wykładającymi idee równouprawnienia w zgodzie z religijnym i społeczno-politycznym programem reformacji. Poetyka listu dedykacyjnego była pochodną retorycznych zasad, praktyki epistolograficznej i oratorskiej (Ocieczek 1990). Autorzy przypisań w omawianych dziełach, wypełniając konwencjonalny formularz dedykacji, nadali swoim listom kształt bliski przemowie, mowie doradczej. Perswazję, niepozbawioną akcentów skargi, a nawet groźby (Boży osąd), modulowała szczególna sytuacja komunikacyjna: prymarnym odbiorcą listu dedykacyjnego był monarcha w republikańskiej Rzeczpospolitej, a prymarnymi nadawcami - Seklucjan, mieszczanin i rzemieślnik z Królewca w lennych Prusach, domenie luterańskiego księcia Albrechta Hohenzollerna oraz pierwsi obywatele Litwy: wojewoda litewski książę Mikołaj Radziwiłł Czarny i książę Krzysztof Radziwiłł jr., hetman polny litewski. Fakt druku uczynił listy dedykacyjne „listami otwartymi” do ogółu czytelników ${ }^{3}$. Perswazyjność tych listów wykraczała daleko poza przedmiot, którego dotyczyły: prezentowały sztukę mówienia do władców ${ }^{4}$ o sprawach wiary i uświadamiały, jak brzmi głos Kościoła, który nie jest hierarchiczną instytucją, lecz wspólnotą świeckich - obywateli, których łączy wspólnota wiary. Listy dedykacyjne do Biblii można zatem usytuować w obrębie toczącego się w XVI i XVII stuleciu wyznaniowego dyskursu.

Sam dar - Biblia - był już swoistą manifestacją konfesyjną i gestem o znaczeniu politycznym. Biblii nie ofiarowują monarsze dostojnicy Kościoła ani duchowni teologowie, lecz osoby świeckie, „wierni poddani”. Postulat powszechnego dostępu do Biblii w języku narodowym realizowany był przy niemałym oporze katolików broniących Tradycji i urzędu

${ }^{3}$ Druk jako nowe medium społecznej komunikacji w XVI wieku w znacznej mierze przesądził o losach wittenberskiego wezwania Lutra do dysputy o usprawiedliwieniu. O reformacji jako, ,pierwszym przypadku praktycznego zastosowania nowożytnej rewolucji medialnej" w aspekcie kształtowania się niemieckiej państwowości (cf. Burkhard 2009: 23-129).

${ }^{4}$ Nawiązuję tu do tytułu pracy Michała Głowińskiego (1989: 80), mistrzowskiej interpretacji pieśni II,14 Jana Kochanowskiego. 
nauczycielskiego Kościoła w wykładzie treści wiary5. Spór o język narodowy w Kościele, o polszczyznę w dyskusjach kontrowersyjnych kwestii teologicznych i religijnych toczył się przez cały XVI wiek. Żądanie polszczyzny in religio było formułowane przez świeckich od pamiętnego laudum szlachty na sejmiku średzkim w 1534 roku domagającego się Biblii w języku polskim. Seklucjan - rzutki wydawca luterańskich tekstów - i pracujący dla niego tłumacz, znakomity grecysta Stanisław Murzynowski, szli w Rzeczpospolitej w awangardzie wielkiego procesu naprawczego ówczesnego zachodniego chrześcijaństwa, także dzięki polskiej Biblii (znaku zerwania z łacińskim, w sensie dosłownym, Kościołem rzymskim). Oddając Zygmuntowi Augustowi Testamentu Nowego część pierwsza (1551), Seklucjan pisał, że tłumaczenie na język polski i wydanie drukiem Pisma Świętego to tytuł do chwały, dumy i szczęścia króla, jego poprzednicy bowiem tego ,ani doczekać, ani mieć mogli”. Swobodne w języku narodowym głoszenie Słowa jest pożyteczne samo przez się, nadto jest warunkiem wolności. Niewola egipska Żydów została tu wskazana jako analogia dla współczesnego królestwa pozostającego poza zasięgiem błogosławionych skutków głoszenia ,,prawej chwały Panu Bogu”. Wyzwolenie z błędów w sprawach wiary, obecność polszczyzny w Kościele i księgach świętych pójdzie w parze z dobrem moralnym we wszystkich sferach życia ${ }^{6}$.

${ }^{5}$ Dedykacja Mikołaja Szarffenbergera w pierwszej drukowanej (1561) polskiej katolickiej Biblii (Leopolity) niemal wyłącznie poświęcona jest obronie polszczyzny; wydawca ani słówkiem nie napomknął o aktualnych kwestiach wyznaniowych i kościelnych, a jednak w dedykacji brzmi echo ówcześnie dyskutowanych problemów wyznaniowych. Oczekiwanie Szarffenbergera, że król weźmie pod swoją obronę ofiarowane mu dzieło, wynikało zapewne $\mathrm{z}$ obawy, iż kościelne władze in corpore nie zaakceptują szerokiego udostępnienia polskiej Biblii. Darowana monarsze polska Biblia była symbolem zmiany, w której nolens volens uczestniczył świat katolicki i wymownym a milczącym postulatem uznania przez monarchę racji strony katolickiej w sporze o „rząd dusz” i wyczulenia monarchy na wagę spraw religijno-wyznaniowych dziejących się w jego królestwie. Wydanie polskiej Biblii nie zniszczy Kościoła - tego każe domyślać się wydawca, czyniąc wzmiankę o Herostratesie, który dla sławy podpalił świątynię Artemidy; współczesny wydawca przeciwnie - nie dla famy, ale dla moralnego i religijnego zbudowania dostarcza tworzywa i wzmacnia fundament wiary Kościoła (Biblia Leopolity 1561: k. $\mathrm{A}_{2}-\mathrm{A}_{2} \mathrm{v}$ ).

${ }^{6}$ Związek języka i moralności, a nad obu - piecza dobrego władcy, to motyw wielu innych wypowiedzi protestantów. W królu widziano obrońcę społeczności identyfikującej się przez wspólny język (Otwinowska 1974: 202-204). 
Do Zygmunta Augusta nie zwracał się Seklucjan jak do monarchy stróża praw Rzeczpospolitej, lecz apelował do indywidualnego sumienia króla, do chrześcijanina znającego wagę Pisma. Dedykację przenikają luterańskie poglądy religijne. Wypowiedzi Seklucjana bliżej do osobistego wyznania wiary niż doradczego votum. Wydawca nie musi prosić ani apelować do króla w żadnej sprawie, nawet życzliwego przyjęcia ofiarowanej mu Biblii czy opieki nad religią. Wszak to nie wolna wola monarchy, ani żadne ludzkie działania okażą swoją skuteczność w różnych sprawach wiedziony luterańskimi ideami religijnymi Seklucjan prezentuje doskonałą postawę fiducji wynikającą z czystej wiary:

Bo ja ufam Panu a Stworzycielowi mojemu, że W.K.M. nad insze pany chrześcijańskie ma na pieczy i przed oczyma Stworzyciela swego i chwałę a słowo świetyj wolej Jego, i nawięcej myśli o nawiętszym rozmnożeniu czci Pańskiej. Gdzie też, nie wątpię w Zbawicielu mojem, iż za łaską Jego W.K.M. swoją czystą sprawą z Słowa Bożego pojętą, w rychle przywiedzie k temu państwo swoje, że Korona Polska będzie błogosławionem przykładem a zwierciadłem prawem prawdziwego ludu Bożego (Testamentu Nowego część wtora a ostateczna 1552: k. $\mathrm{A}_{2}$ ).

Seklucjan nie używa słowa „kościół” i akcentuje indywidualny, osobowy wymiar wiary (,ja ufam”, „nie wątpię w Zbawicielu”), która rozgrywa się na polu indywidualnych rozeznań (także króla), poza instytucjonalnym Kościołem. Świat ludzi wiary przekracza świeckie i kościelne porządki jak pisał Kochanowski w słynnym hymnie Czego chcesz od nas, Panie: „Kościół Cię nie ogarnie, wszędy pełno Ciebie”. Wywód Seklucjana ma mocne oparcie w duchowym rozumieniu Kościoła - congregatio sanctorum.

W dedykacji pełnego Nowego Testamentu wzmocniony został element antykatolicki, pojawił się apel do króla, by „nas wyrwał z ciężkiej niewoli faraonowyj". W argumentacji religijnej znalazły się, tak charakterystyczne dla protestanckiej refleksji, motywy sądu ostatecznego, wiecznego potępienia odrzucających ,poselstwo" Ewangelii o zbawieniu (w postaci luterańskiej). Seklucjan łączy grzecznościowe formuły przynależne adresatowi z bezceremonialnością admonicji: władcy nie uprzywilejowuje jego pozycja, podlega on takiemu samemu prawu Bożemu jak inni chrześcijanie, gdyby bowiem król „Słowem Pańskim wzgardził, ani w nim zbawienia szuka, (...) czego, Panie Boże, racz uchować, żeby na W.K.M ten dekret 
przyszedł, który na człowieka napodlejszego" (Nowy Testament zupełny 1553). Byłby to despekt dla króla, gdyby na sądzie Bożym został potępiony, a „ubożutcy poddani W.K.M. będą za syny Boże przyjęci, którzyby się kolwiek Słowa Pańskiego serdecznie chwycili i przy nim do końca trwali” (Nowy Testament zupetny, 1553).

Wątki przemowy Seklucjana przewijać się będą w liście dedykacyjnym Mikołaja Radziwiłła Czarnego, wielkiego protektora kalwinizmu i mecenasa nowoczesnego przekładu całego Pisma Świętego. Powstawał on zespołowym wysiłkiem w latach 1556-1562. Druk sfinansował Radziwiłł, a jego list dedykacyjny do Zygmunta Augusta wraz z trzystoma egzemplarzami, które rozeszły się po Rzeczpospolitej, powędrował w świat.

Przewodnią myślą dedykacji Radziwiłła jest reformacyjny postulat powrotu do pierwotnego, nieskażonego błędami papistów Kościoła, sięgnięcie wprost do Biblii jako jedynego źródła wiary, uznanie Boga jako jedynego źródła łaski i adresata wszelkiej chwały oraz wyłączności pośrednictwa Chrystusa między Bogiem i ludźmi. Reformacyjna renovatio objąć miała instytucję Kościoła i każdego członka wspólnoty chrześcijańskiej indywidualnie, prowadząc do odrodzenia wiary dzięki autentycznej, niezafałszowanej nauce Chrystusa i apostołów. Krytyczna ocena ziemskiego Kościoła szła w parze z zaufaniem do sprawczej mocy słowa i Biblii, i nowych ,apostołów”. Właśnie w tej roli - świeckiego apostoła (zgodnie z obligiem powszechnego kapłaństwa) - Radziwiłł przedkłada Biblię królowi, który jako „król krześcijański” jest „pomazańcem i wielkim możnym panem, a wodzem ludu Bożego postawion" i tak jak ewangeliczny pasterz dba o „trzodę”, tak ziemski król winien być opiekunem Kościoła. Biblijne analogie będzie mnożyć w rozwinięciu perswazyjnego wywodu, rozpoczyna jednak od znamiennego egzemplum z historii starożytnej spod znaku eleganckiej chrześcijańskiej humanitas, odpowiedniej w dialogu księcia z królem:

A gdyżem w piśmiech historji, acz mało w nich czytając, jako świeckiego stanu człowiek nalazł o tym zmiankę, iż za czasu Ptolomea egiptskiego króla, Demetrijus Falereus, zacny mędrzec, acz Boga prawdziwego nie znał, radził mu, aby w grecki język zakon Boży był przełożon kosztem a staraniem królewskim. Ja tedy udawszy się tym śladem z pobożnej zawiści swojej, z mej majętności, której z wolej Bożej a z poczciwego nabycia przodków mych i z łaski W.K.M. ku mnie używam, tamże swym własnym dobrem a nakładem 
moim uczyniłem rzecz takową, o której mam tę nadzieję, od wszech krześcijańskich ludzi być godna pochwały, między naród słowiańskiego języka po tytułem a imieniem W.K.M. sławnym królewskim, kazałem wydać, to jest, tę świętą lekcyją, księgi Biblijej, Zakon Pierwszy przykazania Bożego, także i Testament Nowy, Ewanjeliją Pana Krystusowę, na polską mowę dawszy przełożyć (Biblia brzeska 1563: k. 2).

Radziwiłł widzi w sobie nowe wcielenie Demetriosa z Faleronu, wybitnego ateńskiego myśliciela, filozofa, polityka, retora, pełniącego urząd archonta, kustosza Biblioteki Aleksandryjskiej, inicjatora przekładu Tory na grekę. Demetrios jest postacią epizodyczną w legendarnej i powszechnie znanej relacji o powstaniu Septuaginty podanej w Liście Arysteasza ${ }^{7}$ (Frankowski 1972: 12-22). List przez wieki dostarczał cennego argumentu na rzecz przekonania o boskim pochodzeniu Septuaginty. Radziwiłł ożywił wielostronne analogie: Ptolemeusz Filadelf - król Zygmunt August, natchnieni tłumacze Septuaginty - tłumacze Biblii działający w Pińczowie pod mecenatem Radziwiłła, on sam - ,zacny mędrzec” Demetrios, spiritus movens przekładu Pisma z języków oryginału wprowadzanego „między naród słowiańskiego języka”, „za społecznym zezwoleniem wszytkich kościołów a zborów krześcijańskich, w państwach W.K.M. tak w Koronie, jako i w Księstwie wedle szczyrego słowa Bożego rozmnożonych".

Jako cel publikacji Radziwiłł wskazuje duchowy i moralny pożytek króla i całej Rzeczpospolitej:

Bo stąd przypatrzy się pierwej każdy temu kresowi, ku któremu prze zbawienie nasze wieczne siebie i żywoty nasze prowadzić mamy. A potym też w tym świętym piśmie i to wszelaki stan najdzie a obaczy i nauczy się tego, począwszy od pana, jako on porządnie Rzeczpospolitę sprawować ma; najdą też i poddani w jakich obyczajoch a postępkoch przystojnych przeciw Bogu i przełożonym swym zostawać mają (...). Abowiem jeśli obietnicam Bożym chcemy wierzyć, jakoż słusznie mamy im wiarę dać, tedy godzi się wszem warstatom ziemskim, aby się im tego nikt nie zabraniał dowiadywać, o czym się rano i wieczór każdy badać ma. Boć jeden gościniec wszytkim do prawice Bożej, tak też zasię, czego nas, Panie Boże, uchowaj i w lewo (Biblia brzeska 1563: k. 2).

${ }^{7}$ Wg Kempfiego Radziwiłł mógł znać List z obszernej relacji Józefa Flawiusza (Dawne dzieje Izraela 12: 12-118) lub z łacińskiego apokryfu, spolszczonego przez Wojciecha Rzymskiego wiele lat przed 1578 r. wyd. 1578). Z całej „kroniki” tłumacz przełożył jedynie fragmenty dotyczące obowiązków władcy i zasad dobrych rządów w państwie, a pominął historię powstania Septuaginty (cf. Kempfi 1959). 
Kolejne egzemplum pochodzi z historii biblijnej: stawia przed królewskie oczy przykład Jozjasza, króla $\mathrm{Judy}^{8}$, który przeprowadził skutecznie reformy religijne, wysunął Torę na pierwszy plan przed tradycję ustną, zwalczał bałwochwalstwo i doprowadził do gruntownego odrodzenia religijnego, „,co dziś takowymże kształtem sam Pan Bóg pobudziwszy k temu moje staranie, do rąk W.K.M. to prawo swoje podawać raczy”. Wywiedziona z 2 Księgi Kronik (34,15-16) analogia Jozjasz - Zygmunt August, Safan („kancerz jego”) - Radziwiłł rezonuje znane z szesnastowiecznej myśli politycznej wyobrażenie dobrego władcy (sprawiedliwego i pobożnego) i mądrych doradców tworzących prawdziwe „seminarium Reipublice"9.

Radziwiłł przywołuje inne przykłady biblijne - słowami Dawida, króla, „proroka i artysty Bożego”, ale też wzoru dla przełożonych różnej rangi, zachęca do duchowego nawrócenia: „Nuż teraz królowie rozumiejcie; ćwiczcie się, którzy sądzicie ziemię"; słowami proroka Daniela grozi bałwochwalcom Bożą pomstą:

jeśliże (...) pójdziem dalej w tenże błąd, który wedle Danielowego proroctwa ten niesromięźliwej twarzy ksiądz rzymskiej bożnice bałwan, zruszyciel dziś jawny pokoju krześcijańskiego, rozsiewacz kąkolu, który w swej zaraźliwej winnicy hojnie rozpłodził to ziarno, jako własny a prawdziwy antykryst, za którym takowym jaszczurczego rodzaju przewodnikiem ślepym, jeślibyś się W.K.M. wdawał aż do końca i nas lud wierny Boży za sobą też prowadzićbyś chciał, by Pan Bóg dla odrzucenia prawdy swej (...) nas za to z Waszą K.M. wszytkich, na zesromocenie, upadek i na podłość, a na zła-

${ }^{8}$ „Przeto we wszej mej pokorze poddanej W.K.M. Pana swego przez imię Boże proszę i napominam, abyś tymi słowy mojemi i tą uprzejmą żądliwością gardzić nie raczył, pamiętając co mędrzec napisał: Podobają się królom usta sprawiedliwe i prawdę mówiącego miłują. A co wiedzieć, że snadź to teraz Pan Bóg czynić raczy, jako w on czas działał, gdy karząc lud swój prze złość i niewdzięczność, odjął był z pośrzodka ich zakon swój, który potym aż za Jozjasza onego dobrego króla okazał na jaśnią przez ręce Elkjasza kapłana i Safana kanclerza jego. Co dziś takowymże kształtem sam Pan Bóg pobudziwszy k temu moje staranie, do rąk W.K.M. to prawo swoje podawać raczy. Czego ja uprzejmem sercem W.K.M. życzę, abyś naśladując przykładu tego tak świętego króla, nas swe poddane do tego wieść, napominać i uczyć raczył, żebyśmy się ustawicznie chwalebnym zakonem Boskim, który od niemałego czasu barzo między nami zaniedbany był, mając go już teraz przed oczyma, onym sprawowali, bawili i ćwiczyli się w nim" (Biblia brzeska 1563, k. 2 v ).

${ }^{9}$ Tak określa rolę kancelarii królewskiej Mirosław Korolko (1991: 87). Z czasem, gdy biegowi spraw wyznaniowych kierunek nadawał sobór trydencki ze swym programem rekatolicyzacji, kancelaria zmieniała oblicze - jak orzekł badacz - „seminarium Reipublice” przekształcało się w ,seminarium episcoporum”. 
manie wieczne, które się już poczęści, niestetysz, między nami zaczyna, przed oczyma inych narodów, (...) w rzeczach pospolitych naszych nie udziałał;

ewangeliczną przypowieścią o pannach głupich i mądrych przestrasza możliwością utraty zbawienia:

które nam przez jedynego Syna swego obiecał dać, nie odraził i nie zamknął brony do chwalebnych przybytków swych, jako przed onymi głupiemi dziewkami fortę zawarł, nie chcąc się więcej ku nam znać, jako to ku kochankom roztuczonym w przysmakach a napojach z kubka tej maszkary babilońskiej, z onym swym sprawiedliwym, ale barzo straszliwym a srogim wyrokiem, od którego apelacja nigdziej nie pójdzie;

przywołuje też wzór pokornego, nawróconego (na judaizm) króla Manassesa.

Cała skrypturalna argumentacja listu odwołuje się do rozsądku i sumienia króla, do monarszej chrześcijańskiej mądrości, do osobistej odpowiedzialności wyłącznie przed Bogiem. Był to obiegowy wątek w piśmiennictwie protestanckim. Chrześcijański rex doctus respektujący i realizujący zasady Ewangelii (jak chciał Erazm: ideał philosophia Christi) gwarantuje prawość i praworządność władzy (rex et lex). Król nie tyle ma dawać przykład, by przekonać nieprzekonanych czy sprzyjać jakiemuś wyznaniu (tu: ewangelicyzmowi), ile majestatem swego urzędu (jako pomazaniec) gwarantować i uosabiać ów moralny ład mający źródło w Ewangelii i Bożym prawie. Dopowiedzmy: w państwie reprezentującym takie wartości, pod sprawiedliwymi rządami chrześcijańskiego króla, szlachta może się „,pięknie różnić”, spokojna o nienaruszalność spoistej całości państwa; takiego władcę bez wątpienia chciała mieć w Zygmuncie Auguście.

Według powszechnej wśród protestantów opinii, król dopiero wtenczas uczyniłby swą władzę zgodną z Boską nauką, gdyby zerwał z Kościołem „papieskim”. Przeciwstawienie bowiem nauki Boskiej nauce kościelnej było źródłem argumentacji także w ideologii politycznej. Wykluczenie pośredników (instytucji Kościoła, papiestwa, duchowieństwa, świętych etc.) - pozwalało „każdemu krześcijańskiemu rycerzowi”, jakby powiedział Rej, dostrzec czystą naukę Ewangelii prowadzącą do zbawienia, a królowi - niezatarte Boskie prawa, których winien strzec i według nich postępować:

Skąd nie tylko W.K.M. samemu szczęścić się będzie, ale i nam wszytkim pod rozkazowaniem twym, gdy patrząc na W.K.M. od błędów w Kościół wniesionych, do Boga 
a Ojca Pana naszego Jezusa Krystusa, ze wszytkiej dusze naszej udamy nawrócimy się, chowając jego Syna świętą Ewanjeliją, jakośmy na to są obowiązani. A wedle tej Ewanjelijej przez Zbawiciela naszego nam podanej, także nauk apostolskich i ceremonij takowych będziem używać, jakich to oboje pismo nas uczy. Na co acz się wszytkim pilno oględać należy, ale jeszcze barziej W.K.M. (Biblia brzeska 1563: k. 2 v).

Jest to wskazówka dla wszelkiego rodzaju przełożonych. Zwierzchnictwo bowiem określa zespół obowiązków, zarówno w królestwie ziemskim, jak i w duchowym. W tym sensie każdy jest „królem”, co Rej (w nawiązaniu do J 4,46-54) tak ujął: „O, mój miły króliku, każdy ty krześcijański człowiecze, któryś jest królikiem nad duszą i nad ciałem swoim i nad szafarstwem tobie do czasu od Pana twego poruczonym, przysłuchawajże się pilno tym świętym słowom Pana tego" (Rej 1965: 245). Nie ma tu miejsca na szczegółową egzemplifikację wskazującą w przebogatym piśmiennictwie reformacyjnym XVI wieku komplet wątków problemowych i ideowych obecnych w dedykacji Mikołaja Radziwiłła (Meller 2004: 48-81) co oczywiste, zważywszy na identyczność ideowo-religijnych przesłanek protestanckich autorów.

Długotrwałe, nie bez trudności i sporów, prace nad nową redakcją protestanckiej Biblii (a dokładnie: zmodernizowaniem tłumaczenia zespołu pińczowskiego), zwieńczyła edycja Biblii gdańskiej. Biblia ta była znakiem nowych czasów, niejako symbolicznym podsumowaniem dążeń protestanckich, których apogeum było już przeszłością, a energię coraz szczuplejszego grona ewangelików wyczerpywały starania o utrzymanie wyznaniowej wolności. Dedykacja Krzysztofa Radziwiłła jr. oddaje Biblię świeżo obranemu na polsko-litewski tron Władysławowi Zygmuntowi. Jest ona echem listu dedykacyjnego Mikołaja Radziwiłła, jednak rezonowała w otoczeniu procesów wywołanych rekatolicyzującym programem soboru trydenckiego. Krzysztof Radziwiłł przywołał więc Zygmunta Augusta jako wzór monarchy, ku któremu „w przodkach naszych ewangelickich (...) taka była weneracyja” z powodu ,cnót Augustowych, a osobliwie wielkiej ku tym narodom i swobodom ich miłości”. Sukcesora króla wsławionego ,pomnożeniem swobód szlacheckich” w imieniu swoim oraz zborów koronnych i litewskich prosi:

abyś W.K.M. tę księgę miłościwie przyjąć raczył. Bo jeśliż król August nie zawiódł się na tym, iż ewangelikom, choć im żadną przysięgą obowiązany nie był, takie dary niosącym przystępny bywał, tedy pogotowiu W.K.M., który już z nami przez świętobliwą 
przysięgę jak przez jaki ślubny pierścień, związany i spojony jesteś, nie zawiedziesz się, da Pan Bóg, gdy temu szczyremu pokłonowi dasz u siebie miejsce ${ }^{10}$ (Biblia gdańska 1632: k. ):(v).

W Biblii nie ma ,żadnych kontrowersyj albo przymówek, które by kogo urażać miały”, a „Zakon Boży - z czyjejkolwiek ręki podany - nie ma u pomazańca Bożego wzgardy albo repulsy ponosić”. Radziwiłł więc nie spodziewa się, by Biblię po polsku spotkała krytyka albo oszczerstwa, bo ,tego o żadnym polskim i litewskim sercu nie rozumiem, aby zapomniawszy krajów, praw i czasów, w których żyjemy, miał to szczyre podarze [podarek] wespół i z religiją naszą ewangelicką przed W.K.M. hydzić”. Istotnie, w owym czasie Krzysztof Radziwiłł mógł odwołać się do obowiązującego w Rzeczpospolitej prawa, tzw. artykułów henrykowskich gwarantujących pokój wyznaniowy, choć sam był uczestnikiem wydarzeń każących powątpiewać w stabilność tego prawa ${ }^{11}$.

Tak jak poprzednicy, Radziwiłł apelował do sumienia i osobistej odpowiedzialności monarchy: „gdy Król nawyższy wzowie przed się wszystkich królów, i gdy z tego, a nie z inszego statutu rachować się z nimi o chwałę swoję Boską i o rząd ludu powierzonego będzie, tedy tam nikt cudzymi nie zasłoni się radami, ale sam za się pojedynkiem odpowiadać musi”. Wytoczył wreszcie koronny argument, że wiara jest darem Bożym, a ludzkie sumienie podlega wyłącznej władzy Boga:

Bóg z niewyczerpanych sądów swoich, tot rerum eventibus, sprzeciwia się wszędzie takowym niechęci królewskich na religiją ewangelicką podżegaczom i pospolitej zgody adwersarzom i dowodzi tego, iż choćby nad o s o b a m i, k s i ę g a m i, z b o r a m i różnowierców górę kto miał, nad m y śl a m i jednak i nad sumnieniami ludzkimi, okrom samej Bożej zwierzchności, nikt panować nie może.

${ }^{10}$ Topikę koronacji króla jako zaślubin z poddanymi warto porównawczo zestawić z obrazowaniem zastosowanym w dedykacji katolickiej Biblii Jakuba Wujka. Jezuiccy „bogomódlcy" widzą w Zygmuncie III Wazie namiestnika Boga i męża opatrznościowego dla Kościoła w Polsce, obranego b o s k i m (a nie ludzkim) wyrokiem, by realizował wolę Boga. W alegorycznej wykładni psalmu 91 prezentowano króla, który dzięki „skrytym i niepojętym sądom Bożym” odnieść ma zwycięski triumf nad heretykami (Biblia Wujka 1599: *2v), w czym wspierają go jezuici.

${ }^{11}$ Krzysztof Radziwiłł jako marszałek sejmu konwokacyjnego w 1632 roku starał się o załatwienie spraw wyznaniowych. Uzgodniona na konwokacji konfederacja generalna warszawska, w której m.in. zaspokojono część postulatów szlachty różnowierczej, po podpisaniu została oprotestowana przez senatorów katolickich. 
W porównaniu z Biblią brzeską wyraźna jest zmiana tenoru przemowy: nie jest ona wezwaniem do przyjęcia czystych prawd Ewangelii, co już się dokonało (mowa wprost o uformowanej „religii ewangelickiej”), ale do respektowania, w imię interesu politycznego państwa, pokoju wyznaniowego i ustanowionych praw. Po siedmiu dekadach, gdy jasne było, że katolicyzm staje się religią dominującą, pozostał tylko postulat: primum non nocere. Taką minimalistyczną intencję wyraża użyty przez Krzysztofa Radziwiłła argument - exemplum z historii starożytnej o Wespazjanie i Apolloniusie ${ }^{12}$ :

Przetoż jako Wespazjanowi, rzymskiemu Cesarzowi, domownik i kochanek jego imieniem Apollonius powiadał, że jeden muzyk, choć w swej profesyjej arcymistrz, przecię swych uczniów do nieumiętnych i ladajakich graczów posyłał, aby się od nich uczyli, nie jako mieli grać, ale jako mieli nie grać; potym to przytoczył do Cesarza, aby on też z tych, którzy źle panowali, uczyć się, jako panować nie miał. Tak i ja zażyłbym tu tego przykładu, abym oczy W.K.M. obrócił na tych, którzy bieg Ewangelijej mocą i gwałtem zawściągając, nie tylko nihil profecerunt, ale i sobie zaszkodzili. Zażyłbym, mówię, tego przykładu, kiedybym nie ufał, że W.K.M. nie cudzymi przygodami, ale własnymi swymi cnotami i chwalebnymi przodków swych przykładami rządząc się, iusto et tranquillo imperio, religionis dissidia moderować będziesz raczył; kiedy bym przytym nie wiedział, że W.K.M. dał Pan Bóg w Ojczyźnie naszej zastać taki Senat i takie rycerstwo, którzy non alienis naufragiis, ale swą własną uwagą i gorącą ku Ojczyźnie miłością ostrzegają się, aby praetextu zeli Rzeczpospolita nasza na skaliste jakie i opoczyste miejsca napędzona nie była (Biblia gdańska 1632: k. ):(v).

Dobro państwa wymaga, by nie wykorzystywać argumentów konfesyjnych w sprawach dotyczących ogółu. Rzeczpospolita winna być wspólną troską: mądrego króla (którego, jak przypomniano we wstępie, „wolnymi naszymi głosami” obrano) i obywateli (szlachty) bez względu na wyznanie. Religijny zelotyzm ustąpić ma przed wartością wyższego rzędu - ładem politycznym, który stale był osnową refleksji o państwie.

Odwrotnie niż w państwach zachodniej Europy, w których spory świeckich z klerem ,,spełniły rolę katalizatora umożliwiającego wykształcenie się instytucji nowożytnego państwa, w Rzeczpospolitej Kościół katolicki wyszedł zwycięsko z konfrontacji ze szlacheckim ruchem reformatorskim, a racja stanu (...) została w 2. poł. XVII w. podporządkowana

${ }^{12}$ Źródłem przypowiastki jest Flawiusza Filostratosa Żywot Apolloniusza z Tiany $(5,35)$, fragment dotyczący pochwały rządów monarchicznych. 
katolicyzmowi” (Augustyniak 2013: 23). Kształtujący się pod wpływem kontrreformacji zwrot kulturowy miał się dokonać pod znakiem doktryny nadrzędności dobra Kościoła (katolickiego). Zanim ten, brzemienny w skutki, proces się dopełnił, a protestanci przeszli na słabszą pozycję obrony wątłej tolerancji, krajobraz wyznaniowy i polityczny XVI wieku wypełnia żywy dyskurs różnych racji w sprawach wyznaniowo-kościelnych.

Listy dedykacyjne sformułowane przez Jana Seklucjana, Mikołaja i Krzysztofa Radziwiłłów reprezentują podobny styl ,sztuki mówienia do władców", eksponują odrębne wątki treściowe, wspólna jednak pozostaje intencja wotów kierowanych do monarchów: król, ciesząc się błogosławieństwem Boga, może panować sprawiedliwie i prowadzić państwo ku szczęściu; strzeże dobra swojego królestwa, zapewniając mu pokój i dbając o wiarę, bo dzięki moralności wywodzonej także z religijnych przesłanek utwierdza się prawość, porządek, ład państwa. Obie dedykacje podnoszą kwestię dobra publicznego; w odróżnieniu od pism z dziedziny filozofii politycznej czy prawnej, w których dominują wywody podparte ideami świeckiej, przede wszystkim antycznej etyki, tezy ofiarodawców Biblii podparte są argumentami religijnymi i dotyczą Kościoła, jednak prowadzą do konkluzji zbieżnych ze świecką myślą o państwie wspólnocie. Cel nadrzędny - dobro wspólne, szczęście doczesne - sprawia, że zobowiązania wobec państwa są prymarne, a jakość ich wykonania zależy w dużej mierze od „porządnej służby Bożej”, religijnej odnowy, odrodzenia Kościoła Chrystusa $^{13}$. Osiągnięcie tego szczęścia, w opinii protestantów, nie wymagało instytucji Kościoła, jednak potrzebna była indywidualna pobożność, kierowanie się zasadami Ewangelii. To z Ewangelii odczytana została idea wzajemnej służby, a nie władzy, co współbrzmiało z politycznym ideałem ustroju mieszanego. Oddanie królowi Biblii było symboliczną ofertą ze

${ }^{13}$ Powyższą refleksję oświetla konstatacja badacza szkolnictwa różnowierczego, który w religijno-społecznym ukierunkowaniu protestanckiej paidei zauważa znamienną różnicę w stosunku do szkolnictwa katolickiego (jezuickiego). Treści nauczania i protestancka pobożność wychowywały „do bezpośredniego zaangażowania w życiu publicznym, do obowiązkowości, odpowiedzialności oraz do innych cnót społecznych" (Budzyński 2003: 471), uczyły etosu pracy i wierności wyznawanej religii. Szkoły różnowiercze realizowały program humanitas i pietas, formując wartości ważne w rzeczywistości ziemskiej i politycznej. Hierarchizowały się one w porządku: B ó g-pań s t w o-o b y w a te 1 (wobec bardziej abstrakcyjnego, konfesyjnego modelu rzymskokatolickiego: Bóg - Kościół - chrześcijanin) (Budzyński 2003: 471). 
strony reprezentowanych przez darczyńców obywateli (a nie poddanych): utwierdzona wolność religijna i religijno-moralna odnowa zbuduje, jak współcześnie powiedzielibyśmy, wysoki kapitał społeczny, który działać będzie dla dobra doczesnego królestwa.

\section{Literatura}

Augustyniak U., 2013, Państwo świeckie czy księże? Spór o rolę duchowieństwa katolickiego w Rzeczypospolitej w czasach Zygmunta III Wazy. Wybór tekstów, Warszawa, s. 7-121.

Biblia brzeska, 1563, Biblia święta, to jest księgi Starego i Nowego Zakonu, Brześć, k. nlb. $1-3$.

Biblia gdańska, 1632, Biblia święta, to jest księgi Starego i Nowego przymierza, Gdańsk, druk. A. Hünefeld, k. ):( - ):(2v).

Biblia Leopolity, 1561, Biblia, to jest księgi Starego i Nowego Zakonu, Kraków, k. $\mathrm{A}_{2}-\mathrm{A}_{4}$. Biblia Wujka, 1599, Biblia, to jest ksiegi Starego i Nowego Testamentu, Kraków, k. *2-*3. Budzyński J., 2003, Paideia humanistyczna czyli wychowanie do kultury. Studium $z$ dziejów klasycznej edukacji w gimnazjach XVI-XVIII wieku (na przykładzie Ślaska), Częstochowa.

Burkhard J., 2009, Stulecie reformacji w Niemczech (1517-1617). Między rewolucja medialna a przełomem instytucjonalnym, przeł. J. Górny, Warszawa.

Czapska M., 1928, Polemika religijna pierwszego okresu reformacji w Polsce, „Reformacja w Polsce" r. 5, s. 8-15.

Flawiusz Filostratos, 1997, Żywot Appoloniusza z Tiany, przeł. I. Kania, Kraków, s. 219-221.

Frankowski J., 1972, List Arysteasza, czyli legenda o powstaniu Septuaginty, „Ruch Biblijny i Liturgiczny" z. 1, s. 12-22.

Głowiński M., 1989, Sztuka mówienia do władców, w: Jan Kochanowski. Interpretacje, red. J. Błoński, Kraków, s. 80-87.

Kempfi A., 1959, O tłumaczeniu Kroniki Arysteasza jako jednej z parenez politycznych w piśmiennictwie polskim XVI wieku, Warszawa.

Korolko M., 1991, Seminarium Rzeczypospolitej Królestwa Polskiego. Humaniści w kancelarii królewskiej Zygmunta Augusta, Warszawa.

Kriegseisen W., 2010, Stosunki wyznaniowe w relacjach państwo-kościót między reformacja a oświeceniem (Rzesza Niemiecka - Niderlandy Pótnocne - Rzeczpospolita polsko-litewska), Warszawa, s. 7-217, 411-673.

Meller K., 2004, „,Noc przeszła, a dzień się przybliżył”. Studia o polskim piśmiennictwie reformacyjnym XVI wieku, Poznań, s. 15-82.

Nowy Testament zupetny, 1553, Królewiec.

Ocieczek R., 1990, O różnych aspektach badań literackiej ramy wydawniczej w książkach dawnych, w: O literackiej ramie wydawniczej w ksiązkach dawnych, red. R. Ocieczek, Katowice, s. 7-20. 
Otwinowska B., 1974, Język - naród - kultura. Antecedencje i motywy renesansowej myśli o języku, Warszawa, s. 119-270.

Pietrzyk-Reeves D., 2010, O pojęciu „,Rzeczpospolita” (res publica) w polskiej myśli politycznej XVI wieku, „Czasopismo Prawno-Historyczne” t. 62, z. 1, s. 37-63.

Rej M., 1965, Postylla (wydanie fototypiczne), cz. 2, Wrocław.

Sucheni-Grabowska A., 1994, Obowiązki i prawa królów polskich w opiniach pisarzy epoki odrodzenia, w: Między monarchia a demokracją. Studia z dziejów Polski XVI-XVIII wieku, red. A. Sucheni-Grabowska, M. Żaryn, Warszawa, s. 53-115.

Sucheni-Grabowska A., 1996, Zygmunt August król polski i wielki książe litewski 1520-1562, Warszawa, s. 303-322.

Testamentu Nowego część pierwsza,1551, Królewiec.

Testamentu Nowego część wtora a ostateczna, 1552, Królewiec.

Winiarska I., 2004, Stownictwo religijne polskiego kalwinizmu od XVI do XVIII wieku na tle terminologii katolickiej, Warszawa, s. 272-288. 